\title{
SARS-CoV-2 infection - spread and pathogenicity
}

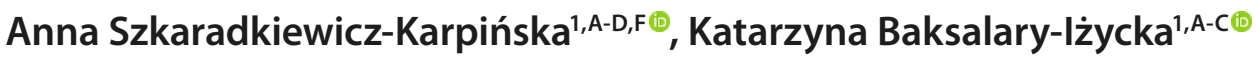 \\ 1 Department of Preclinical Conservative Dentistry and Preclinical Endodontics, University of Medical Sciences, Poznań, \\ Poland \\ A - Research concept and design, B - Collection and/or assembly of data, C - Data analysis and interpretation, \\ $D$ - Writing the article, $E$ - Critical revision of the article, $F$ - Final approval of article
}

\author{
Szkaradkiewicz-Karpińska A, Baksalary-lżycka K. SARS-CoV-2 infection - spread and pathogenicity. J Pre-Clin Clin Res. 2020; 14(2): 49-51. \\ doi: $10.26444 / j p c c r / 123118$
}

\begin{abstract}
I Abstract
In December 2019, a new disease, similar to severe acute respiratory syndrome (SARS), was reported in Wuhan, China. It was quickly indicated that the causative agent of this new coronavirus disease 2019 (COVID-19) is a previously unknown coronavirus, now called SARS coronavirus 2 (SARS-CoV-2). The result of the global outbreak of COVID-19 in the world (currently COVID-19 is present on all continents, except Antarctica) is the pandemic status 2019-2020, as declared by the WHO and Public Health Emergency of International Concern (PHEIC).The virus has a high epidemic potential and is effectively transmitted between humans. The primary route for SARS-CoV-2 infection to spread is air-droplet transmission. In addition, SARS-CoV-2 can be transmitted through direct contact with an infected person, or indirectly via coronavirus-contaminated materials or objects. Current data also indicate the possibility of an alternative route of SARS-CoV-2 infection - through the gastrointestinal tract. The article discusses various SARS-CoV-2 transmission options, with particular attention paid to the role of saliva and gastrointestinal tract in the spreading of the virus. Current data on SARS-CoV-2 pathogenicity and clinical symptoms of COVID-19 are also analyzed. Expanding knowledge about SARS-CoV-2 infection, especially in terms of its spread, will contribute to further actions aimed at preventing transmission of this pathogen.
\end{abstract}

\section{Key words}

SARS-CoV-2, saliva, dentistry, gastrointestinal infection, COVID-19

\section{INTRODUCTION}

In December 2019, in the city of Wuhan, Hubei Province, China, there emerged a new disease with an unexplained etiology. Symptoms of the disease were similar to severe acute respiratory syndrome (SARS), but infection with SARS$\mathrm{CoV}$ and MERS-CoV as causative factors were excluded [1]. At the beginning of January 2020, the new virus was identified and described as 2019-novel coronavirus (2019$\mathrm{nCoV}$ ) [2]. The World Health Organization (WHO) named the virus severe acute respiratory syndrome coronavirus 2 (SARS-CoV-2) and caused the rapid spread worldwide of coronavirus disease 2019 - COVID-19 (the name of this disease was introduced and recommended for use by the WHO). SARS-CoV-2 belongs to the Coronaviridae family, Betacoronavirus genus, and is phylogenetically closely related to other SARS-like coronaviruses $[3,4]$. The result of the global outbreak of COVID-19 (currently COVID-19 is present on all continents, except Antarctica) is the pandemic status 2019-2020, declared by the WHO and the Public Health Emergency of International Concern (PHEIC) on 11 March 2020 [5].

\footnotetext{
Address for correspondence: Anna Szkaradkiewicz-Karpińska, Department of Preclinical Conservative Dentistry and Preclinical Endodontics, University of Medical Sciences, Poznań, Poland

E-mail: aniaszk@op.pl

Received: 28.04. 2020; accepted: 30.05.2020; first published: 22.06.2020
}

\section{OBJECTIVE}

SARS-CoV-2 has a high epidemic potential. Knowledge about possible transmission routes of SARS-CoV-2 is therefore particularly necessary for more effective reduction of its transmission. The aim of the study is to present current scientific data about possibilities of spreading SARS-CoV-2 between humans, and its pathogenicity.

Spreading of SARS-CoV-2. It is already well known that SARS-CoV-2 is efficiently transmitted between humans. Cases of familial clustering have been reported [6,7] and it is currently accepted that SARS-CoV-2 is one of the super-spreading pathogens. The main, human-to-human transmission occurs through respiratory droplets when inhaled air contains saliva with secreted droplets from respiratory tract during coughing, sneezing, and some surgical/medical procedures [8, 9]. In addition, SARS-CoV-2 can be infected through direct contact with an infected person or indirectly via coronaviruscontaminated materials or objects $[4,9]$. Recently, a very high viral load contained in the saliva from patients with COVID-19 (reaching $1.2 \times 10^{8}$ copies $/ \mathrm{ml}$ ) and the possibility of virus transmission via saliva among patients without coughing or other respiratory symptoms, are indicated [10]. It is also suggested that the presence of SARS-CoV-2 in the oral cavity can result from major- or minor-salivary gland infection, with subsequent release of particles in saliva via the salivary ducts [10]. This suggestion may be supported by earlier studies documenting that salivary gland epithelial cells can be infected by SARS-CoV within a short time after infection in rhesus macaques [11]. The presented data prove that human saliva may play a significant role in the spreading of SARS-CoV-2. 
COVID-19 is therefore a new and serious problem in dentistry. Possible virus transmission through direct contact with saliva droplets and aerosols, generated during dental clinical procedures, is a reason for the high prevalence of COVID-19 among dentists [12]. Indirect contact infection is also possible: SARS-CoV-2 has the ability to survive on paper or copper surfaces from $4-24$ hours, on steel instruments for at least 48 hours, and 72 hours on plastic surfaces [13]. In light of the above, the use of diagnostics of SARS-CoV-2 in patients' saliva could improve effective strategies for COVID-19 prevention, especially for dentists and healthcare professionals who perform aerosol-generating procedures.

Current data also indicate the possibility of an alternative route of SARS-CoV-2 infection - through the gastrointestinal tract [14]. The presence of live SARS-CoV-2 or viral nucleic acids has been shown in stool samples of patients. The occurrence of gastrointestinal symptoms in some patients with COVID-19 may confirm that digestive tract as a potential source of faecal-oral transmission of SARS-CoV-2 $[15,16]$.

SARS-CoV-2 pathogenicity. SARS-CoV-2 is characterized by tropism to human cells, showing specific receptors angiotensin-converting enzyme 2 (ACE 2) and co-localized in its proximity - cellular transmembrane serine protease 2 (TMPRSS 2) $[17,18]$. ACE 2 determines virus attachment to the target cells, while TMPRSS 2 is necessary for viral entry into cells and for viral spreading in the infected host [18]. ACE 2 is expressed commonly on the surface of epithelial and endothelial cells. Its high expression was found on type 2 lung alveolar cells (AT2), oesophagus upper and stratified epithelial cells, cholangiocytes, myocardial cells, kidney proximal tubule cells, and bladder urothelial cells [19, 20]. It has also been shown that high expression of ACE 2 can occur on mucosa of the oral cavity, especially on the oral tongue [19]. In addition, ACE 2 expression was found on lymphocytes within oral mucosa or various organs of the digestive system, and in the lungs [17].

The presented data indicate that although SARS-CoV-2 pathogenicity is manifested principally in respiratory tract, other organs can also be involved. The replication cycle of SARS-CoV-2 takes place in the cytoplasm of target cells, similarly as in most RNA viruses. However, the unique way of replication strategy of coronaviruses (via the transcription of multiple subgenomic RNAs serve as mRNAs for the structural and accessory genes) allows for a very high recombination frequency, which ensures their genetic variability and the emergence of new strains. The process of virus assembly and formation of progeny viral particles is associated with cellular membrane structures of the cell, called ERGIC (endoplasmic reticulum-Golgi intermediate compartment) [9]. Mature progeny viruses are released from cells by exocytosis. SARSCoV-2 may exert a cytopathic effect (expressed in some SARS patients by the presence of multinucleated syncytial cells) leading to cytolysis, which initiates lung pathology [21]. However, the association of pulmonary damage with severe inflammation in SARS-CoV-2 infection with focal peribronchiolar mononuclear inflammatory infiltrates, is also very possible $[22,23]$. The pathogenesis of SARS-CoV-2 infection in humans and lung injury remains unclear. Lung pathology found in COVID-19 is difficult to explain only by the impact of the virus per se.

Recently, it has been indicated that the severity of COVID-19 is accompanied by a significant increase in inflammatory cytokines, mainly IL-6, as well as high levels of $\mathrm{D}$-dimer in peripheral blood $[24,25]$. These data suggest that SARS-CoV-2 may induce a cytokine storm, which is the result of an overreaction of the immune system in COVID-19 patients, resulting in severe pneumonia, acute respiratory distress syndrome (ARDS), and multiple organ dysfunction syndrome (MODS).

COVID-19 - clinical symptoms. Although SARS-CoV-2 infection may involve many organs, the most common and the most severe are respiratory symptoms of COVID-19 [23, $26]$. The incubation period of the disease is $2-14$ days, usually $3-7$ days. The earliest common symptoms of COVID-19 are fever, cough and dyspnea. Recently presented meta-analysis reports their occurrence as follows: $87.3 \%, 58.1 \%$ and $38.3 \%$, respectively [27]. It has also been reported that frequent clinical feature are atypical pneumonia $(75.7 \%)$ and ground glass opacification (69.9\%) in chest X-ray.

Among analyzed patients, the incidence of ARDS was found in $28.8 \%$ and MODS in $8.5 \%$. Patients with COVID-19 may also present, although less often, symptoms of damage to various other organs, such as: oral tongue, kidney, liver and small intestine. Most often, the manifestations of the disease include symptoms from the gastrointestinal tract, e.g. diarhoea, nausea/vomiting and abdominal pain. Meta-analysis reported the occurrence of these symptoms as follows: $9 \%, 6 \%$ and $4 \%$, respectively [28]. In addition, approximately $60 \%$ of COVID-19 patients had liver impairment, indicating SARS-CoV-2-associated hepatotoxicity, including elevated aminotransferases, hypoproteinaemia, and prothrombin time prolongation [20]. SARS-CoV-2 infection can also be asymptomatic, often especially in children up to 14 years old $(28.6 \%)$ and adults $\geq 70$ years $(27.3 \%)[29,30]$. Children and the elderly can be estimated as the main population with asymptomatic infection. This phenomenon is difficult to explain only by the reduced effectiveness of the immunological response, especially in the context of the possibility of the rapid spread of SARS-CoV-2 in the host organism.

\section{CONCLUSIONS}

SARS-CoV-2 infection represents a global and serious health and life concern for people worldwide; therefore, knowledge about possible transmission routes is essential. The article presents the important role of saliva in the spread of the virus and its potential faecal-oral transmission. In addition, it has been pointed out that COVID-19 pathogenesis is not only determined by SARS-CoV-2 activity per se, but may also be the result of a strong inflammatory response of the host organism. Simultaneously, it is worth notification is that SARS-CoV-2 infection can often be asymptomatic, mainly in children under the age of 14 years, and adults less than 70 years old.

\section{REFERENCES}

1. World Health Organization. Pneumonia of unknown cause - China. 2020 https://www.who.int/csr/don/05-january-2020-pneumonia-ofunkown-cause-china/en/

2. World Health Organization. Novel coronavirus - China. 2020. https:// www.who.int/csr/don/12-january-2020-novel-coronavirus-china/en/ 
3.https://www.who.int/emergencies/diseases/novel-coronavirus-2019. (accessed on 21 April 2020).

4. Lu R, Zhao X, Li J, Niu P, Yang B, Wu H, et al. Genomic characterisation and epidemiology of 2019 novel coronavirus: implications for virus origins and receptor binding. Lancet. 2020; 395(10224): 565-574.

5.https://www.who.int/news-room/detail/27-04-2020-who-timeline-covid-19 6. Chan JF, Yuan S, Kok KH, To KK, Chu H, Yang J, et al. A familial cluster of pneumonia associated with the 2019 novel coronavirus indicating person-to-person transmission: a study of a family cluster. Lancet. 2020; 395(10223): 514-523.

7. Centers for Disease Control and Prevention. 2019 Novel coronavirus, Wuhan, China: 2019-nCoV situation summary. Appendices January 28, 2020 https://www.cdc.gov/coronavirus/2019-ncov/summary.html

8. Centers for Disease Control and Prevention. Infection control. 2019 Novel coronavirus, Wuhan, China. 2020 https://www.cdc.gov/coronavirus/2019ncov/hcp/clinical-guidance-management-patients.html

9. Szkaradkiewicz A. Novel human coronaviruses - SARS-CoV, MERSCoV and 2019-nCoV (COVID-19). Zakażenia XXI wieku. 2020; 3(1): $1-6$.

10. To KK, Tsang OT, Chik-Yan Yip C, Chan KH, Wu TC, Chan JMC, et al. Consistent detection of 2019 novel coronavirus in saliva. Clin Infect Dis. 2020; doi: 10.1093/cid/ciaa149

11.Liu L, Wei Q, Alvarez X, Wang H, Du Y, Zhu H, et al. Epithelial cells lining salivary gland ducts are early target cells of severe acute respiratory syndrome coronavirus infection in the upper respiratory tracts of rhesus macaques. J Virol. 2011; 85(8): 4025-4030.

12. Spagnuolo G De Vito D, Rengo S, Tatullo M. COVID-19 Outbreak: an overview on dentistry. Int J Environ Res Public Health. 2020; 17(6). doi: 10.3390/ijerph17062094

13. van Doremalen N, Bushmaker T, Morris DH, Holbrook MG, Gamble A, Williamson BN, et al. Aerosol and surface stability of SARS-CoV-2 as compared with SARS-CoV-1. N Engl J Med. 2020 doi: 10.1056/ NEJMc2004973.

14.Zhang H, Kang Z, Gong H, Xu D, Wang J, Li Z, et al. The digestive system is a potential route of 2019-nCov infection: a bioinformatics analysis based on single-cell transcriptomes. bioRxiv. doi: https://doi org/10.1101/2020.01.30.927806

15. Gu J, Han B, Wang J. COVID-19: Gastrointestinal Manifestations and Potential Fecal-Oral Transmission. Gastroenterology. 2020. doi: 10.1053/j.gastro.2020.02.054

16. Holshue ML, DeBolt C, Lindquist S, Lofy KH, Wiesman J, Bruce H, et al. First case of 2019 novel coronavirus in the United States. N Engl J Med. 2020; 382(10): 929-936.

17.Zou X, Chen K, Zou J, Han P, Hao J, Han Z. Single-cell RNA-seq data analysis on the receptor ACE2 expression reveals the potential risk of different human organs vulnerable to 2019-nCoV infection. Front Med. 2020. doi: 10.1007/s11684-020-0754-0
18. Hoffmann M, Kleine-Weber H, Schroeder S, Krüger N, Herrler T, Erichsen S, et al. SARS-CoV-2 cell entry depends on ACE2 and TMPRSS2 and is blocked by a clinically proven protease inhibitor. Cell. 2020. https://doi.org/10.1016/j.cell.2020.02.052

19. Xu H, Zhong L, Deng J, Peng J, Dan H, Zeng X, et al. High expression of ACE2 receptor of 2019-nCoV on the epithelial cells of oral mucosa. Int J Oral Sci. 2020; 12, 8. doi.org/10.1038/s41368-020-0074-x

20. Chai XQ, Hu LF, Zhang Y, Han W, Lu W, Ke A. Specific ACE2 expression in cholangiocytes may cause liver damage after $2019-\mathrm{nCoV}$ infection. bioRxiv. doi.org/10.1101/2020.02.03.931766

21. Sims AC, Baric RS, Yount B, Burkett SE, Collins PL, Pickles RJ. Severe acute respiratory syndrome coronavirus infection of human ciliated airway epithelia: role of ciliated cells in viral spread in the conducting airways of the lungs. J Virol. 2005; 79(24): 15511-15524.

22. Huang Ch, Wang Y, Li X, Ren L, Zhao J, Hu Y, et al. Clinical features of patients infected with 2019 novel coronavirus in Wuhan, China. Lancet. 2020; 395: 497-506.

23. Wang D, Hu B, Hu C, Zhu F, Liu X, Zhang J, et al. Clinical characteristics of 138 hospitalized patients with 2019 novel coronavirus-infected pneumonia in Wuhan, China. JAMA. 2020. doi: 10.1001/jama.2020.1585

24. Wan SX, Yi RJ, Fan SB, Lv JL, Zhang XX, Guo L, et al. Characteristics of lymphocyte subsets and cytokines in peripheral blood of 123 hospitalized patients with 2019 novel coronavirus pneumonia (NCP). medRxiv. /doi.org/10.1101/2020.02.10.20021832

25. Lin L, Lu L, Cao W, Li T. Hypothesis for potential pathogenesis of SARS-CoV-2 infection-a review of immune changes in patients with viral pneumonia. Emerg Microbes Infect. 2020; 9(1): 727-732.

26. Wu Z, McGoogan JM. Characteristics of and important lessons from the coronavirus disease 2019 (COVID-19) outbreak in China summary of a report of 72314 cases from the Chinese Center for Disease Control and Prevention. JAMA. 2020; 323(13): 1239-1242.

27. Cao Y, Liu X, Xiong L, Cai K. Imaging and clinical features of patients with 2019 novel coronavirus SARS-CoV-2: A systematic review and meta-analysis. J Med Virol. 2020. doi: 10.1002/jmv.25822

28. Heydari K, Rismantab S, Shamshirian A, Lotfi P, Shadmehri N, Houshmand P. Clinical and paraclinical characteristics of COVID-19 patients: A systematic review and meta-analysis. medRxiv. doi. org/10.1101/2020.03.26.20044057

29. Qiu H, Wu J, Hong L, Luo Y, Song Q, Chen D. Clinical and epidemiological features of 36 children with coronavirus disease 2019 (COVID-19) in Zhejiang, China: an observational cohort study. Lancet Infect Dis. 2020; doi.org/10.1016/ S1473-3099(20)30198-5

30. Tao Y, Cheng P, Chen W, Wan P, Chen Y, Yuan G. High incidence of asymptomatic SARS-CoV-2 infection, Chongqing, China. medRxiv; 2020. doi: $10.1101 / 2020.03 .16 .20037259$ 